\title{
Mechanisms of the Fasting-Induced Increase in Insulin Binding to Rat Adipocytes
}

\author{
Jerrold M. Olefsky and MaSashi Kobayashi, Division of Endocrinology and \\ Metabolism, Stanford University School of Medicine, Stanford, California 94305, \\ and the Palo Alto Veterans Administration Hospital, Palo Alto, California 94304
}

A B S T R A C T Fasting leads to an increase in the ability of adipocytes to bind insulin, and this was accounted for by an increase in the affinity of the receptors for insulin without any change in the number of receptors per cell. Binding affinity can increase because of a decrease in the dissociation rate constant $\left(k_{d}\right)$, an increase in the association rate constant $\left(k_{a}\right)$, or both. Kinetic studies demonstrated that fasting leads to a striking decrease in the rate at which insulin dissociates from its receptor, and the near two-fold prolongation of the time at which $50 \%$ of the bound ${ }^{125}$ I-insulin dissociates $(28 \pm 4$ vs. $50 \pm 5 \mathrm{~min}$ ) correlated quite well with the two-fold increase in binding affinity. On the other hand, the rate at which insulin associates with its receptor was essentially unchanged. Negatively cooperative interactions between receptors were readily demonstrated in cells from control and fasting animals, and the magnitude and sensitivity of this effect was the same in both groups of cells. It seemed likely that during fasting a change in the concentration of some substrate or hormone could lead to these effects on insulin binding. However, in vitro attempts to recreate the substrate and hormonal changes which occur in fasting produced no evidence to support this idea. In conclusion: $(a)$ fasting leads to an increase in the ability of adipocytes to bind insulin because of an increase in binding affinity; (b) this increase in the affinity of the receptor for insulin was primarily accounted for by a decrease in the rate at which insulin dissociates from its receptors; and $(c)$ fasting did not appreciably alter the negatively cooperative interactions displayed by adipocyte insulin receptors.

Dr. Olefsky is a Clinical Investigator with the Veterans Administration. During the course of this work, Dr. Kobayashi was a Postdoctoral Research Fellow of the National Institute of Arthritis, Metabolism, and Digestive Diseases of the National Institutes of Health.

Received for publication 18 April 1977 and in revised form 6 October 1977.

\section{INTRODUCTION}

The ability of target cells to bind insulin does not represent a fixed biologic process, and cells are able to modulate their ability to specifically bind the hormone. Most commonly, changes in insulin binding have been due to changes in the number of insulin receptors per cell, and many examples of this type of "regulation" resulting from experimental perturbations (1-3) and pathophysiologic changes have been documented (3, 4). Recently, we have found that as little as $24 \mathrm{~h}$ of fasting leads to an increase in insulin binding to isolated adipocytes because of an increase in the affinity of the receptor for insulin (5). Thus, modulation of receptor affinity can also occur, indicating that this may be an important mechanism for the more acute regulation of insulin binding. Furthermore, this phenomenon is not confined to adipocytes, since Bar et al. (6) have demonstrated comparable fasting-induced increases in insulin receptor affinity in circulating monocytes from obese patients.

In the current studies, we have investigated the mechanism of this fasting-induced increase in receptor affinity by examining the kinetics of the insulin binding reaction, cooperative interactions between insulin receptors, and exposure of cells to some of the chemical alterations associated with the fasting state. The data indicate that, in fasting, binding affinity is primarily regulated by modulating the rate at which insulin dissociates from its receptor.

\section{METHODS}

Materials. Porcine monocomponent insulin was generously supplied by Dr. Ronald Chance of the Eli Lilly \& Co., (Indianapolis, Ind.). ${ }^{125} \mathrm{I}-\mathrm{Na}$ and $\left[{ }^{14} \mathrm{C}\right]$ insulin were purchased from New England Nuclear (Boston, Mass.), bovine serum albumin (fraction V) from Armour Pharmaceutical Co. (Phoenix, Ariz.), $\beta$-hydroxybutyrate, acetoacetate, oleate, and glucagon from Sigma Chemical Co. (St. Louis, Mo.), collagenase from Worthington Biochemical Corp. (Freehold, N. J.), and epi- 
nephrine from Parke, Davis \& Co. (Detroit, Mich.). Human growth hormone was a gift from the National Institutes of Health hormone distribution program.

Animals. Male Sprague-Dawley rats were used for all experiments. Control animals weighed between 140 and 160 $g$ and were fed ad lib. until the morning of all studies. 48-h-fasted animals were deprived of food at 8 a.m., approximately $48 \mathrm{~h}$ before sacrifice. Initial and final weights of fasting animals were $178 \pm 4$ and $152 \pm 4 \mathrm{~g}$, respectively. Mean adipocyte volume was $62 \pm 6 \mathrm{pl} /$ cell for control rats v. $51 \pm 3$ $\mathrm{pl} /$ cell for fasting animals. Morning plasma insulin and glucose levels declined from $36 \pm 6$ to $6 \pm 3 \mu \mathrm{U} / \mathrm{ml}$ and from $132 \pm 6$ to $114 \pm 4 \mathrm{mg} / 100 \mathrm{ml}$, respectively, as a result of the fast.

Preparation of isolated adipocytes. All studies were begun between 8 and 9 a.m. Animals were stunned by a blow to the head and decapitated, and epididymal fat pads were removed. Isolated fat cells were prepared by shaking at $37^{\circ} \mathrm{C}$ for $60 \mathrm{~min}$ in Krebs-Ringer bicarbonate buffer containing collagenase $(3 \mathrm{mg} / \mathrm{ml})$ and albumin $(40 \mathrm{mg} / \mathrm{ml})$, according to the method of Rodbell (7). Cells were then filtered through $250=\mu \mathrm{m}$ nylon mesh, centrifuged at $400 \mathrm{rpm}$ for $4 \mathrm{~min}$, and washed two times in buffer. Adipocyte counts were performed according to a modification of method III of Hirsch and Gallian $(8)$, in which the cells were fixed in $2 \%$ osmium tetroxide in $0.05 \mathrm{M}$ collidine buffer (made isotonic with saline) for $24 \mathrm{~h}$ at $37^{\circ} \mathrm{C}$ and then taken up in a known volume of $0.154 \mathrm{M} \mathrm{NaCl}$ for counting. Counting was performed using a model ZB Coulter Counter with a $400-\mu \mathrm{m}$ aperture, and all data from every experiment were normalized to a cell concentration of $2 \times 10^{5}$ cells $/ \mathrm{ml}$. Cell size was determined according to the method of Di Girolamo et al. (9).

Iodination of insulin. ${ }^{125} \mathrm{I}$-insulin was prepared at sp act $100-150 \mu \mathrm{Ci} / \mu \mathrm{g}$ according to Freychet et al.'s modification (10) of the method of Hunter and Greenwood (11), as previously described (12).

Binding studies. Isolated fat cells were suspended in a buffer containing $35 \mathrm{mM}$ Tris, $120 \mathrm{mM} \mathrm{NaCl}, 1.2 \mathrm{mM} \mathrm{MgSO}_{4}, 4$ $\mathrm{mM} \mathrm{KCl}, 10 \mathrm{mM}$ glucose, $1 \mathrm{mM}$ EDTA, and $1 \%$ bovine serum albumin (13), pH 7.6, and incubated for $90 \mathrm{~min}$ with ${ }^{125} \mathrm{I}$-insulin and unlabeled insulin in plastic flasks in a $24^{\circ} \mathrm{C}$ shaking water bath as previously described $(14,15)$. The incubations were terminated, as described by Gammeltoft and Gliemann (16), by removing $200-\mu$ l aliquots from the cell suspension and rapidly centrifuging the cells in plastic microtubes to which $100 \mu \mathrm{l}$ of silicone oil had been added. Silicone oil has a specific gravity intermediate between buffer and cells, and therefore, after centrifugation, three layers result: cells on top, oil in the middle, and buffer on the bottom. The cells were then removed and the radioactivity was determined. All studies were done in triplicate. Insulin degradation was monitored by assessing the ability of the ${ }^{125}$ I-insulin remaining in the incubation media to precipitate with $10 \%$ trichloroacetic acid. At the end of the 90-min incubations, degradation was minimal (3-8\%) and equal with cells from control and fasting animals.

Dissociation studies. All dissociation studies were performed at $24^{\circ} \mathrm{C}$ according to a modification (17) of the approach originally described by De Meyts et al. (18). Adipocytes were allowed to reach steady-state binding conditions $(90 \mathrm{~min})$ with a tracer amount of ${ }^{125} \mathrm{I}$-insulin $\left(0.6 \mathrm{ng} / \mathrm{ml}\right.$ or $\left.10^{-10} \mathrm{M}\right)$ in a total volume of $3 \mathrm{ml}$. At this point, the cells were centrifuged ( $3 \mathrm{~min}$ at $400 \mathrm{rpm}$ ) and the buffer was removed and replaced with an equal amount of insulin-free media at $6^{\circ} \mathrm{C} .^{1}$ The cells were

${ }^{1}$ Exposure of adipocytes to $6^{\circ} \mathrm{C}$ for this brief period of time did not lead to cell clumping or breakage, and homogeneous cell suspensions were readily achieved by gentle brief agitation. Prolonged exposure of cells to $6^{\circ} \mathrm{C}$ buffer or vigorous mixing does lead to clumping and lysis. then distributed in $100-\mu$ l aliquots into tubes containing $1.9 \mathrm{ml}$ of buffer at $24^{\circ} \mathrm{C}$ with added unlabeled insulin (dilution + insulin) or with no added insulin (dilution only). The cells in these tubes were then centrifuged through $0.5 \mathrm{ml}$ of silicone oil at the indicated time points, and the radioactivity remaining in the cell layer was determined. Although there was no appreciable decrease in the amount of specifically bound ${ }^{125} \mathrm{I}$-insulin before and after the $6^{\circ} \mathrm{C}$ centrifugation and washing steps, binding at time zero ( $100 \%$ bound, Figs. 3 and 4$)$ is given as the amount of radioactivity bound to cells in a 100- $\mu$ l aliquot taken after centrifugation and washing at $6^{\circ} \mathrm{C}$, and just as cells were distributed into the dissociation tubes (containing $1.9 \mathrm{ml}$ of buffer). The mean ( $\pm \mathrm{SE}$ ) counts per minute (before normalization to $2 \times 10^{5}$ cells) were $2,394 \pm 378$ and $3,616 \pm 512$ for control and fasting studies, respectively. All samples were counted for $10 \mathrm{~min}$. Using $\left[{ }^{14} \mathrm{C}\right]$ inulin to assess extracellular water space (19), it was found that in the final dissociation incubations, the original extracellular media is diluted $>500$ fold. Methodologic experiments have shown that this degree of dilution is more than enough to assure that essentially no unbound ${ }^{125}$ I-insulin is carried through from the original binding incubation, and that rebinding of ${ }^{125} \mathrm{I}$-insulin which dissociated from the cells is insignificant. In this way, dissociation rates of ${ }^{125} \mathrm{I}$-insulin can be compared at different levels of receptor occupancy, including essentially zero occupancy (dilution only).

Nonspecific binding. In these experiments, nonspecific binding is defined as the amount of ${ }^{125} \mathrm{I}$-insulin remaining in the cell layer in the presence of a large excess $(200 \mu \mathrm{g} / \mathrm{ml})$ of unlabeled insulin. When cells equilibrate with a tracer concentration of ${ }^{125} \mathrm{I}$-insulin $(0.6 \mathrm{ng} / \mathrm{ml})$, only $3-7 \%$ of the bound insulin represents nonspecific binding. As previously demonstrated $(15,20)$, much of this is accounted for by "trapped" buffer, and nonspecifically bound insulin dissociates rapidly from the cells $(21,22)$ during the dissociation phase of the experiment. Therefore, although correction for nonspecific binding has been carried out, this represents only a trivial difference under these conditions.

Preparation of other cell types. Isolated circulating mononuclear cells were prepared according to previously described methods (23). IM-9 cultured lymphocytes were maintained in culture and prepared for binding studies as described by Gavin et al. (1).

Effect of substrates and hormones on insulin binding. In experiments employing $\beta$-hydroxybutyrate, acetoacetate, oleate, epinephrine, glucagon, or human growth hormone, these agents were used at the concentrations given in the tables. Results were the same whether these agents were added at the beginning of the binding incubation, or whether various preincubation times (up to $24 \mathrm{~h}$ ), temperatures $\left(15^{\circ}-37^{\circ} \mathrm{C}\right)$, or buffers were employed.

\section{RESULTS}

Fig. 1A depicts the competition curves of steady-state binding data of isolated adipocytes from control and 48-h fasting rats. It is evident that the ability of cells from fasting animals to bind insulin is increased, and that the differences are much greater at the lower insulin concentrations. This indicates that the increased insulin binding seen in fasting is primarily due to an increase in receptor affinity, and this point is made clear by analyzing the Scatchard plots of these data (Fig. 1B). With this method of analysis, the slope of the curve reflects the binding affinity and the $x$ intercept represents the number of insulin receptor sites per cell. 

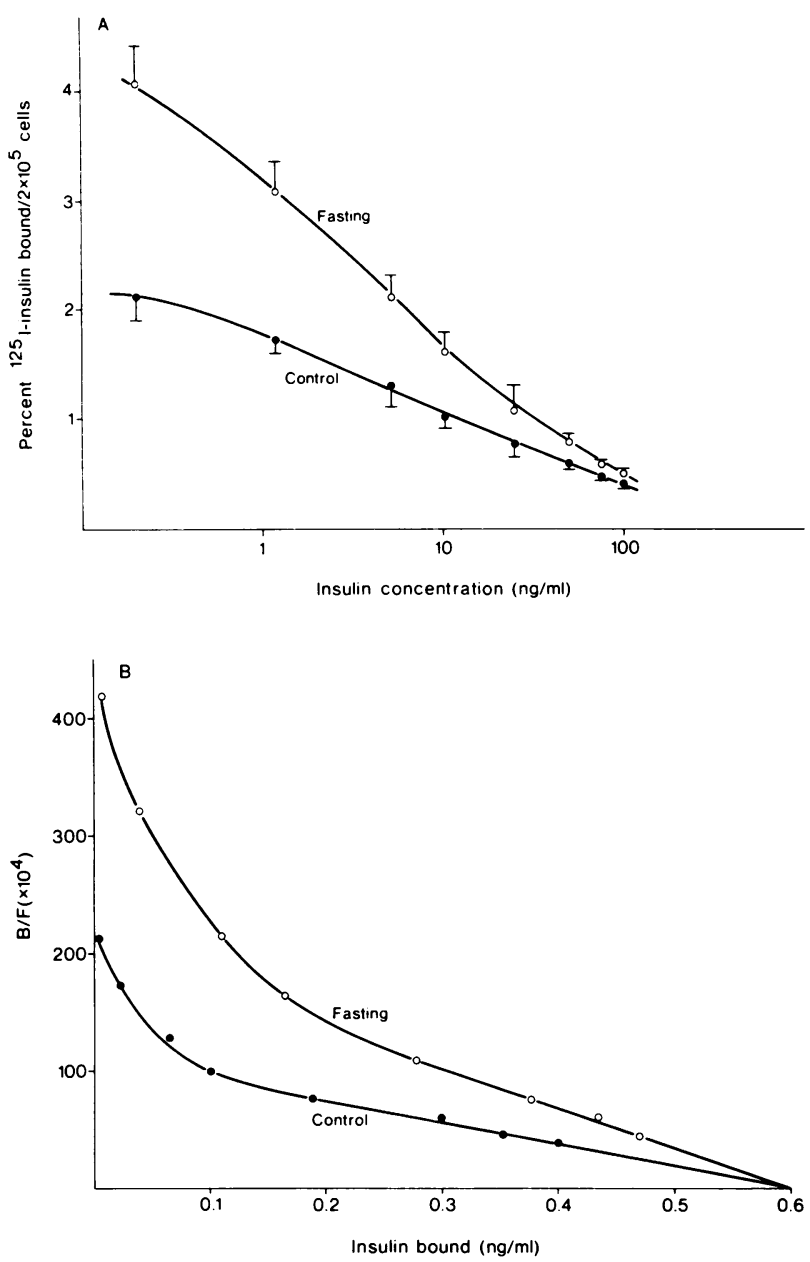

FIGURE 1 (A)Ability of adipocytes from control (O) and 48-h fasting $(O)$ animals to specifically bind ${ }^{125} \mathrm{I}$-insulin. Data represent the mean $( \pm S E)$ of five separate experiments performed on different batches of cells on different days for each group. Cells were incubated for $90 \mathrm{~min}$ at $24^{\circ} \mathrm{C}$, with 0.2 $\mathrm{ng} / \mathrm{ml}^{125} \mathrm{I}$-insulin plus unlabeled insulin to give the indicated total insulin concentration $(5,15,20)$. All data are corrected for nonspecific binding $(5,15,20)$ and are normalized to a cell concentration of $2 \times 10^{5}$ cells $/ \mathrm{ml}$. (B)Scatchard plots of the insulin binding data in $\mathrm{A}$ above. The ratio of bound to free hormone $(\mathrm{B} / \mathrm{F})$ is on the ordinate, and bound hormone is on the abscissa.

As previously demonstrated (5), the curve from the fasting animals is steeper than that from control, while the horizontal intercept is the same. Thus, cells from fasting animals have a higher overall affinity for insulin but have the same number of receptor sites as control cells $(\sim 300,000$ sites/cell).

However, since these plots are curvilinear, affinity constants cannot be readily calculated, and De Meyts has demonstrated that the curvilinearity is due, at least in part, to negatively cooperative interactions between receptor sites $(18,22,24)$. Furthermore, we have

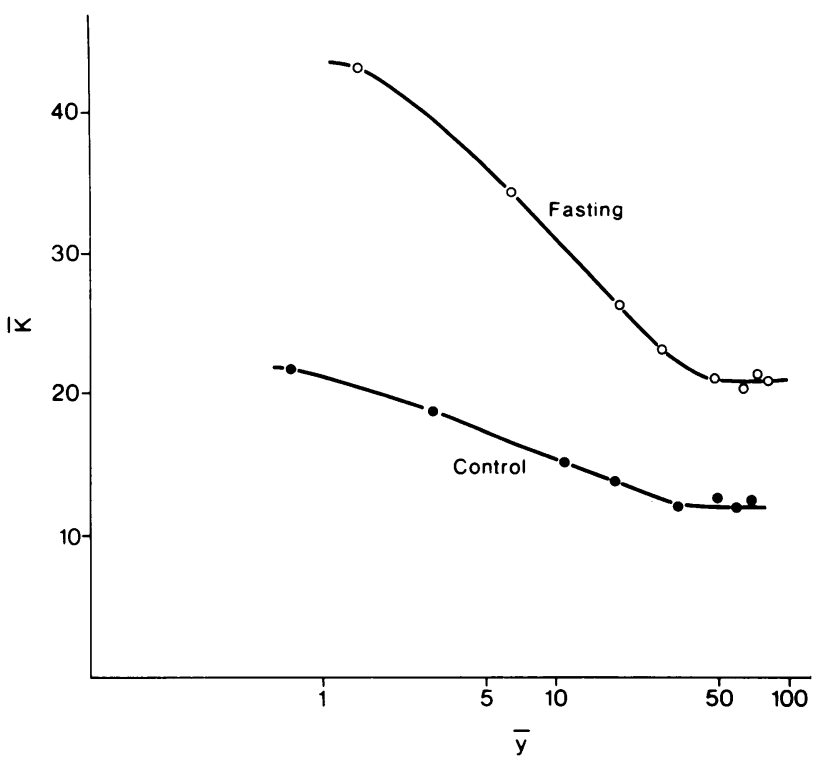

Figure 2 Average affinity profile (25) of insulin binding data from control and 48-h fasted rats. The average affinity $(\tilde{K})$ equals $\left[(B / F) /\left(R_{0}-B\right)\right] \times 10^{7}$ and is plotted as a function of fractional receptor occupancy $(\bar{y})$. $\bar{y}$ equals the fraction of the total number of available receptors which are occupied, and is computed by dividing the amount bound $(B)$ by $R_{0}$ (the total receptor concentration as calculated from the abscissal intercept of the Scatchard plot). With this analysis, the highest observable $\bar{K}$ is designated $K_{e}$, or "empty" site affinity, and the lowest $\bar{K}$ observed is designated $K_{f}$. The $\bar{y}$ at which $K_{f}$ is reached is designated $y_{f}$. For comparative purposes, we have termed the fractional occupancy which leads to a $50 \%$ decrease in $\bar{K}$ as $C_{\frac{1}{2}}$. This provides an estimate of the degree of occupancy needed to induce half of the maximal negative cooperative effect.

recently demonstrated that similar interactions exist between adipocyte insulin receptors (17). Therefore, to analyze these changes in affinity more precisely, the data have been plotted on an average affinity graph (Fig. 2 ), as described by De Meyts and Roth (25). With this analysis, the average affinity of the receptors is plotted as a function of fractional receptor occupancy. As can be seen, the average affinity $(\bar{K})$ falls as a function of receptor occupancy (negative cooperativity) until the lowest observed affinity $\left(K_{f}\right)$ is reached. The fractional occupancy necessary to produce $K_{f}$ is designated $y_{f}$, and $K_{e}$ represents the highest observed affinity of the receptors and is exhibited in the native or "empty site" state. As can be seen, this analysis indicates that fasting leads to an increase in both the "empty site" affinity $\left(K_{\rho}\right)$ and the lowest affinity $\left(K_{f}\right)$. On the other hand, the fractional occupancy needed to achieve a given decrease in the average affinity is approximately twice as great in fasting. Thus, $50 \%$ of the decrease in $\bar{K}$ is reached at a fractional receptor occupancy $\left(\mathrm{C}_{1 / 2}\right)^{2}$ of $5 \%$

${ }^{2}$ In this context $\mathrm{C}_{1}$ simply refers to the fractional receptor occupancy at which $50 \%$ of the fall in $\bar{K}$ is observed. 
and $11 \%$ in cells from control and fasting rats, respectively. Therefore, with this analysis, all assessments of receptor affinity are increased by fasting, and the fall in $\bar{K}$ with increasing occupancy, due to negative cooperativity, is less for any given fractional receptor occupancy. Lastly, the ratio of $K_{f} / K_{e}$ is disignated $\alpha$ and represents the potency of the cooperative effect. This ratio is $\sim 0.5$ for both curves and suggests that the magnitude of the cooperative phenomenon is essentially unchanged by fasting.

In Eq. 1, the general scheme for the insulin binding reaction is given, where $[R]$ equals the free receptor concentration, $[\mathrm{I}]$ equals the free hormone concentration, and [IR] is the amount of insulin bound.

$$
[\mathrm{I}]+[\mathrm{R}] \underset{k_{d}}{\stackrel{k_{a}}{\rightleftarrows}}=[\mathrm{IR}]
$$

In Eq. 2, it can be seen that the affinity constant of the binding reaction $\left(K_{A}\right)$ is equal to the ratio of the association rate constant $\left(k_{a}\right)$ and the dissociation rate constant $\left(k_{d}\right)$.

$$
K_{A}=\frac{k_{a}}{k_{d}}=\frac{[\mathrm{HR}]}{[\mathrm{H}][\mathrm{R}]}
$$

Thus, the increase in receptor affinity $\left(K_{A}\right)$ seen in fasting can be due to a decrease in $k_{d}$, an increase in $k_{a}$, or both. To examine the first of these possibilities, insulin dissociation was studied using adipocytes prepared from control and fasting animals. This was accomplished by allowing cells to associate with a tracer concentration of ${ }^{125} \mathrm{I}$-insulin $(0.6 \mathrm{ng} / \mathrm{ml})$ and then measuring dissociation in insulin-free buffer. These data are summarized in Fig. 3, which clearly shows that fasting leads to a significant decrease in the rate at which insulin dissociates from adipocytes. Since these curves are multiexponential, a single-order $k_{d}$ cannot be computed; however, to estimate differences between the curves, the time at which $50 \%$ of the previously bound ${ }^{125}$ I-insulin dissociates from the cells can be calculated. With this approach, the one-half dissociation time is $28 \pm 4 \mathrm{~min}$ for control cells vs. $50 \pm 5 \mathrm{~min}$ for cells from fasting animals. These studies were done in insulin-free buffer, under conditions in which $<1 \%$ of the receptors are initially occupied, and thus represent insulin dissociation in the absence of negative cooperative interactions. However, De Meyts et al. $(18,22,24)$ have shown that insulin receptors of cultured lymphocytes and liver membranes exhibit negative cooperativity, and we have found that adipocyte receptors have similar properties (17). Therefore, to assess the effect of fractional receptor occupancy on insulin dissociation in fasting, and to quantitate the influence of fasting on the cooperative interactions between receptor sites, we performed the studies presented in Figs. 4 and 5.

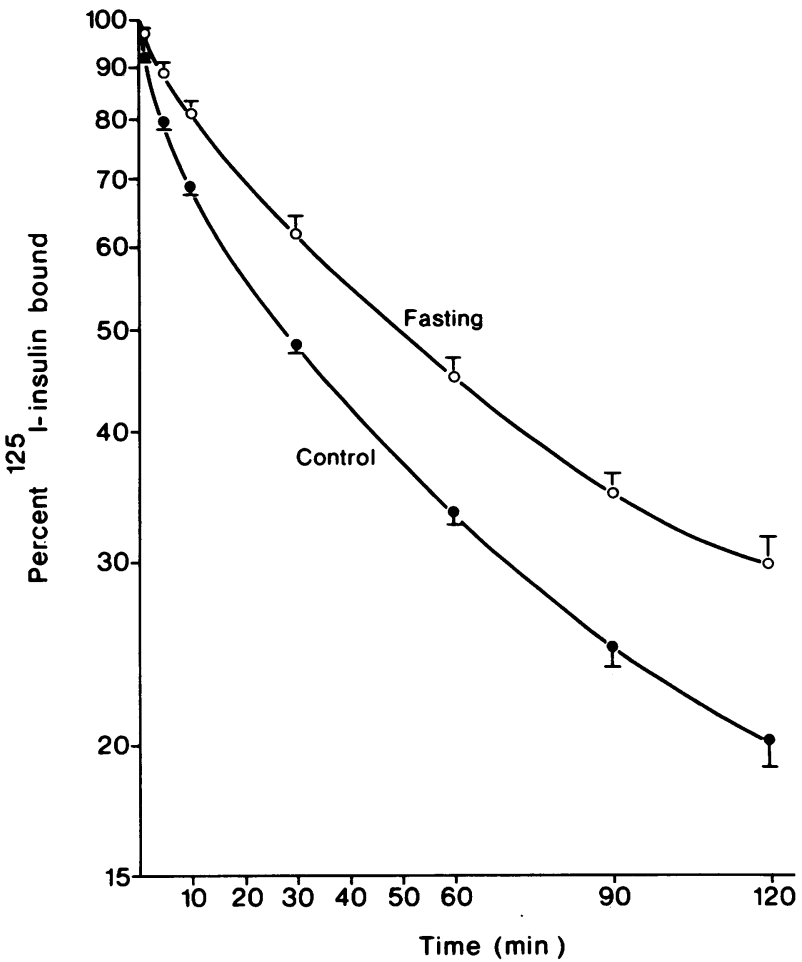

Figure 3 Dissociation of ${ }^{125} \mathrm{I}$-insulin into insulin-free media using adipocytes obtained from control $(O)$ and 48-h fasting $(O)$ animals. Cells are first allowed to equilibrate with $0.1 \mathrm{nM}$ ${ }^{125}$ I-insulin, and then are "infinitely" diluted into insulin-free buffer. The rate at which the previously bound ${ }^{125} \mathrm{I}$-insulin dissociates from the cells is determined by measuring the amount of ${ }^{125} \mathrm{I}$-insulin which remains bound at the indicated time points. For measurement of nonspecific binding, parallel tubes are treated identically, except for the presence of 200 $\mu \mathrm{g} / \mathrm{ml}$ unlabeled insulin throughout the entire experiment. Nonspecific binding was trivial ( $<3 \%$ of the counts bound) under the conditions of this experiment, but all data were still corrected for this factor. Nonspecific binding was equal and minimal for both groups of cells. Before normalization to $2 \times 10^{5}$ cells, the average $( \pm \mathrm{SE})$ counts per minute at time zero ( $100 \%$ bound) were $3,194 \pm 478$ and $4,916 \pm 612$ for cells from control and fasting animals, respectively. Data represent the mean $\pm \mathrm{SE}$ of 11 separate experiments for each group and are expressed per $2 \times 10^{5}$ cells $/ \mathrm{ml}$.

Fig. 4 depicts dissociation studies performed in the presence (dilution + insulin) and absence (dilution only) of $100 \mathrm{ng} / \mathrm{ml}$ unlabeled insulin in the dissociation phase of the experiment. Clearly, dissociation of the ${ }^{125}$ I-insulin is faster in the presence of unlabeled insulin for both groups of cells. Thus, the higher fractional receptor occupancy produced by the unlabeled insulin accelerates dissociation, and this process has been termed "negative cooperativity" $(18,22,24)$. The absolute magnitude of this effect is comparable in both groups of cells. However, in fasting, dissociation is slower in the absence of insulin, and therefore it remains slower in the presence of $100 \mathrm{ng} / \mathrm{ml}$ insulin 


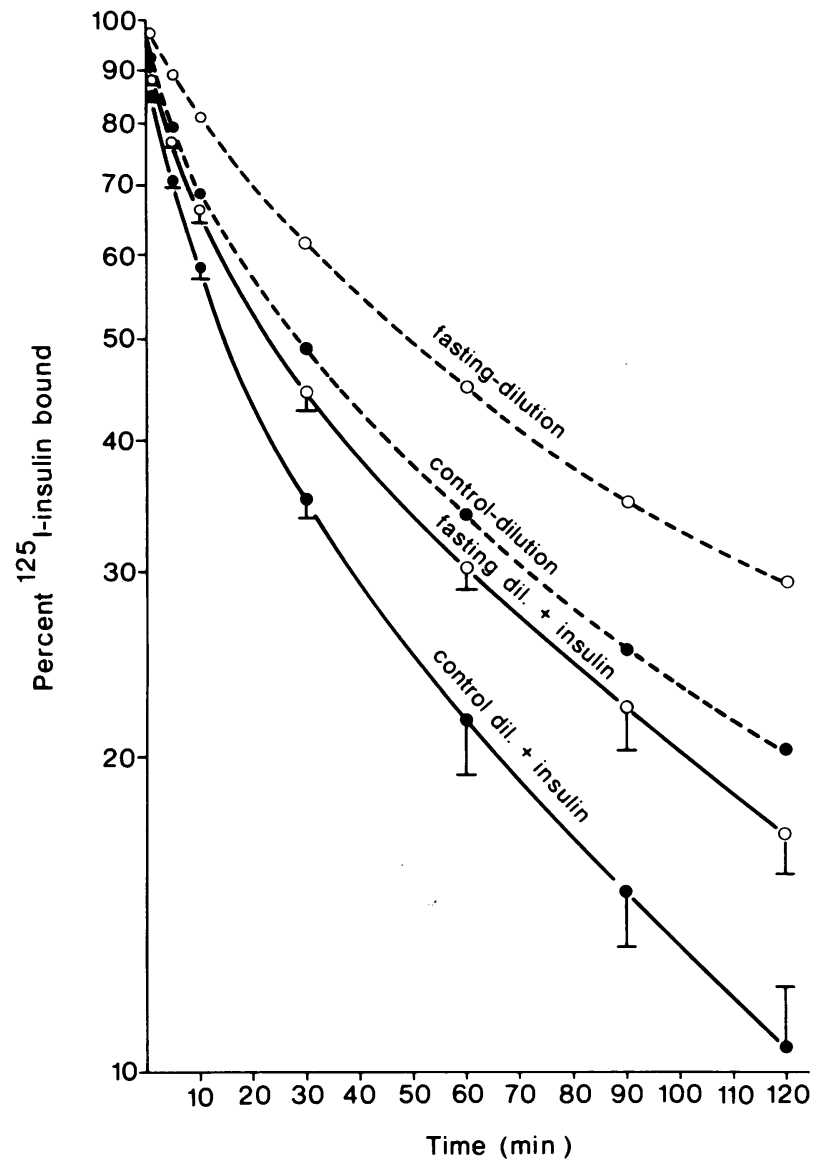

FIGURE 4 Effect of unlabeled insulin on dissociation of ${ }^{125}$ I-insulin from both groups of adipocytes. Cells are treated in the same way as described in Fig. 3, except that the diluting media now contained $100 \mathrm{ng} / \mathrm{ml}(16.6 \mathrm{nM})$ unlabeled insulin. As originally described by De Meyts et al. (18), the high fractional receptor occupancy achieved by the unlabeled insulin accelerates the dissociation of the previously bound ${ }^{125} \mathrm{I}-$ insulin, a phenomenon termed "negative cooperativity". Data from control $(\bigcirc)$ and fasting $(O)$ animals represent the mean $\pm \mathrm{SE}$ of eight separate experiments. Results from the "dilution only" studies are presented (broken lines) for comparative purposes. At $180 \mathrm{~min}$ of dissociation (data not plotted), the percent of ${ }^{125}$ I-insulin remaining bound to the cells was 15,12 , 8 , and $3 \%$ for the fasting dilution control dilution, fasting dilution + insulin, and control ditution + insulin experiments, respectively.

despite a similar magnitude of the cooperative (or accelerating) effect.

To compare the sensitivity of the cooperative effect to the insulin concentration used in the dissociation phase, we performed insulin dose-response studies, (Fig. 5). As can be seen, the shapes of these doseresponse curves are similar, indicating that fasting does not lead to an appreciable change in the sensitivity of the cooperative phenomenon. In this figure, the cooperative effect at each insulin concentration is

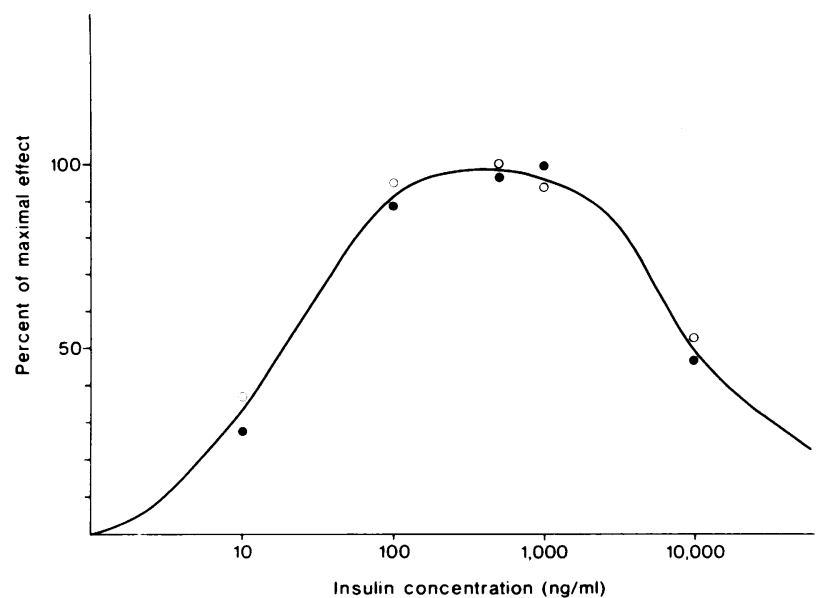

FIGURE 5 Effect of insulin concentration (dilution + insulin) to accelerate the dissociation of bound ${ }^{125}$ I-insulin using cells from control $(O)$ and fasting $(O)$ animals. The difference between the amount of ${ }^{125} \mathrm{I}$-insulin dissociating from the cells in the presence of dilution alone versus dilution + insulin is expressed as a percent of the maximal effect and plotted as a function of the insulin concentration in the dissociation medium (dilution + insulin). The actual experimental data from both groups of cells is given in Table I.

plotted as a percent of the maximal effect for comparative purposes. The actual experimental data (mean $\pm \mathrm{SE}$ ) are presented in Table I, which gives the percent insulin dissociated (at $10 \mathrm{~min}$ ), in the absence (dilution only) or presence of the indicated insulin levels in the dissociation phase. By comparing the differences between the first column (dilution only) and the remaining columns, it can be seen that the absolute acceleration of dissociation is essentially the same for both groups of cells. A similar dose-response relation-

TABLE I

Ability of Unlabeled Insulin to Accelerate the Dissociation of Bound ${ }^{125}$ I-Insulin*

\begin{tabular}{ccccccc}
\hline & $\begin{array}{c}\text { Dilution } \\
\text { only } \\
\end{array}$ & 0 & \multicolumn{5}{c}{ Insulin concentration in dissociation phase $(\mathrm{ng} / \mathrm{ml})$} \\
\cline { 3 - 7 } & 10 & 100 & 500 & 1,000 & 10,000 \\
\hline Control & $29 \pm 2$ & $33 \pm 3$ & $40 \pm 2$ & $42 \pm 3$ & $43 \pm 4$ & $34 \pm 1$ \\
Fasting & $19 \pm 2$ & $25 \pm 2$ & $33 \pm 2$ & $35 \pm 2$ & $34 \pm 3$ & $28 \pm 3$
\end{tabular}

* Data represent absolute percent of ${ }^{125} \mathrm{I}$-insulin which has dissociated from the cells at $10 \mathrm{~min}$. Numbers in the first column (dilution only) represent the percent of ${ }^{125} \mathrm{I}$-insulin which dissociates at $10 \mathrm{~min}$ in the absence of unlabeled insulin in the dissociation phase. Subsequent columns are the absolute percent of ${ }^{125} \mathrm{I}$-insulin dissociated when the indicated unlabeled insulin concentration is present in the dissociation phase. The difference between the numbers in the first column (dilution only) and the subsequent columns gives the absolute acceleration of dissociation achieved at each concentration. The data are the mean $\pm \mathrm{SE}$ of six separate experiments for each group. 
ship for the cooperative effect has been reported by De Meyts et al. (18, 22, 24).

Next, the rate at which insulin associates with its receptors was assessed by examining the time course of ${ }^{125} \mathrm{I}$-insulin binding. Fig. $6 \mathrm{~A}$ depicts the association data, in absolute terms, for both groups of cells. The shapes of the curves are similar, but the actual amount bound is higher for the cells from the fasting animals, and this would be predicted from the data in Fig. 1. To compare the rate of association on a uniform basis, we plotted the data as a percent of the maximal amount bound (Fig. $6 \mathrm{~B}$ ). With this analysis, the curves are essentially superimposable, but more importantly, the initial slopes are the same; this indicates that $k_{a}$ is similar for both groups. These experiments were conducted at a tracer ${ }^{125} \mathrm{I}$-insulin concentration $(0.2$ $\mathrm{ng} / \mathrm{ml}$ ), and analogous results are seen when association is studied at higher insulin concentrations where the receptors become relatively saturated (data not shown).

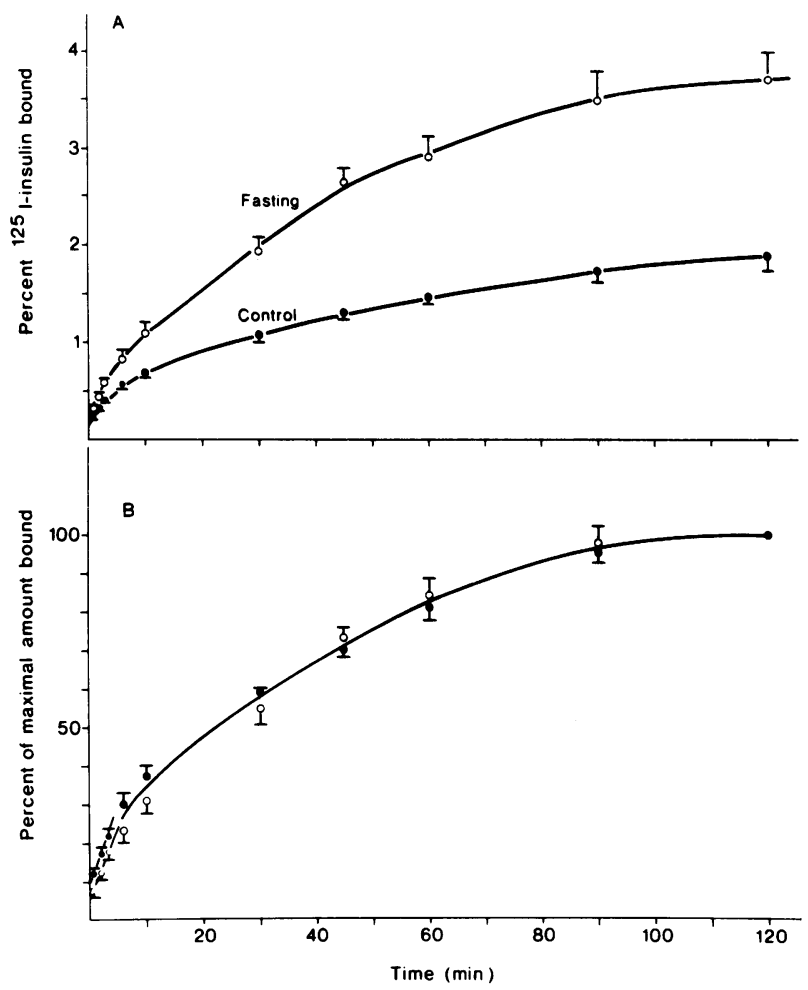

FIGURE 6 Time course of insulin binding to cells from control (O) and fasting (O) rats. (A) Data represent the mean $\pm \mathrm{SE}$ of five separate experiments for each group and are expressed as the absolute percentage of the ${ }^{125} \mathrm{I}$-insulin specifically bound at each time point. Each study was conducted at an insulin concentration of $33 \mathrm{pM}$, and results are normalized to a cell concentration of $2 \times 10^{5}$ cells $/ \mathrm{ml}$. (B) Results in A above expressed as a percent of the maximal amount bound. The data over the initial part of the time course are essentially linear, and straight lines have been drawn through these points to allow comparison of the initial slopes of the binding reaction.

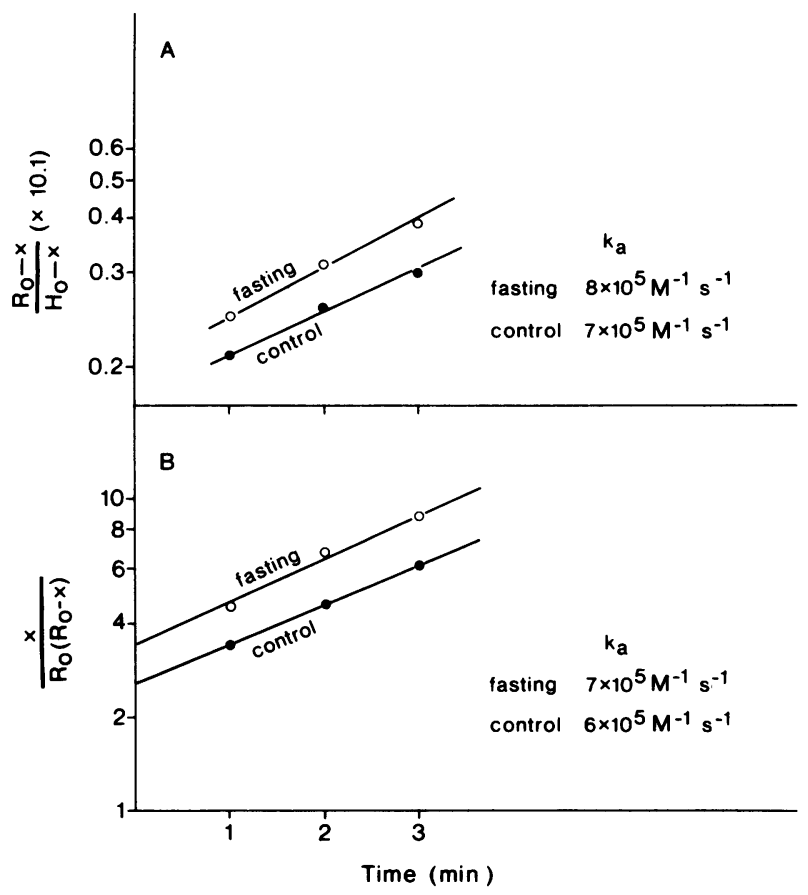

FIGURE 7 Second-order rate plot of the initial part of the binding reaction using cells from control $(O)$ and fasting $(O)$ rats. (A) Data are computed from the second order rate equation $\mathrm{t}=\frac{1}{k(a-b)} \cdot \ln \frac{b(a-x)}{a(b-x)}$, where $b=$ insulin concentration $\left(\mathrm{H}_{0}\right)$ at $\mathrm{t}=0$ (or $33 \mathrm{pM}$ ), $a=\mathrm{R}_{0}$ (as calculated from Scatchard plots) (or $66.7 \mathrm{pM}$ ), and $x=$ amount bound. $\mathrm{t}$ is plotted against $\log (a-x) /(b-x)$, where $\frac{1}{a-b} \cdot \ln \frac{b}{a}$ is constant. This approach applies when $a \neq b$. (B) Results are obtained from experiments where $a$ and $b$ are equal $(66.7 \mathrm{pM})$. Data are computed from the second-order rate equation for $a=b$, i.e., $k \mathrm{t}=\frac{x}{a(a-x)}$, where $a=\mathbf{R}_{0}=\mathbf{H}_{0}$, and $x=$ the amount bound at each time point. The ordinate scale has been multiplied by $10^{7}$.

The association data can also be analyzed by use of a second-order rate equation, and this graph is presented in Fig. 7. It should be pointed out that this approach can only approximate $k_{a}$, since in this case, the product (insulin receptor complexes) can dissociate back to the reactants (free insulin and unoccupied receptors). Furthermore, because of the possibility that the adipocyte insulin receptors may not be functionally homogeneous $(17,26)$, even this estimated rate constant may not have the usual precise physicochemical meaning (it may represent an "average" rate constant). Despite these qualifications, if linearity is observed, then this analysis approximates $k_{a}$ and is useful for comparative purposes. As can be seen, the data are essentially parallel over the first $3 \mathrm{~min}$ of the reaction, and this indicates that very little dissociation occurs during this time. This is consistent with the idea that the 
TABLE II

In Vitro Effect of Various Substrates and Hormones on Insulin Binding*

\begin{tabular}{|c|c|c|c|}
\hline Additions & Adipocytes & $\begin{array}{c}\text { IM-9 } \\
\text { lympho- } \\
\text { cytes } \downarrow\end{array}$ & $\begin{array}{l}\text { Circulating } \\
\text { mononuclear } \\
\text { cells }\end{array}$ \\
\hline None (control) & 100 & 100 & 100 \\
\hline \multicolumn{4}{|l|}{$\beta$-Hydroxybutyrate, } \\
\hline $4 \mathrm{mM}$ & 100 & - & - \\
\hline $8 \mathrm{mM}$ & 96 & 99 & 94 \\
\hline $15 \mathrm{mM}$ & 100 & 101 & - \\
\hline \multicolumn{4}{|l|}{ Acetoacetate, } \\
\hline $1 \mathrm{mM}$ & 101 & 101 & - \\
\hline $5 \mathrm{mM}$ & 101 & 102 & 98 \\
\hline Oleate, $1 \mathrm{mM} \S$ & 94 & 102 & - \\
\hline \multicolumn{4}{|l|}{ Epinephrine, } \\
\hline $1 \mu \mathrm{M}$ & 107 & - & - \\
\hline $10 \mu \mathrm{M}$ & 92 & - & - \\
\hline \multicolumn{4}{|l|}{ Glucagon, } \\
\hline $1 \mathrm{nM}$ & 96 & - & - \\
\hline $10 \mathrm{nM}$ & 98 & - & - \\
\hline \multicolumn{4}{|l|}{ Growth hormone, } \\
\hline $1 \mathrm{nM}$ & 105 & - & - \\
\hline $10 \mathrm{nM}$ & 94 & - & - \\
\hline $\begin{array}{l}\beta \text {-Hydroxybutyrate }(8 \mathrm{mM}) \\
\quad+\text { Epinephrine }(1 \mu \mathrm{M}) \\
\quad+\text { Glucagon }(1 \mathrm{~nm}) \\
\text { + Growth hormone }(1 \mathrm{~nm})\end{array}$ & 98 & 101 & - \\
\hline $\begin{array}{l}\text { Plasma from } 48 \text {-h-fasted rats } \\
(50 \% \mathrm{vol} / \mathrm{vol})\end{array}$ & 99 & 97 & - \\
\hline
\end{tabular}

* Data are expressed as percent of control, and none of these differences approached statistical significance. Results represent the mean of two to seven experiments for each item, and all studies were done at a single ${ }^{125} \mathrm{I}$-insulin concentration of $0.2 \mathrm{ng} / \mathrm{ml}$.

\$ IM-9 lymphocytes were cultured in RPMI 1640 media containing $5 \%$ fetal calf serum at $37^{\circ} \mathrm{C}$. For binding studies, cells were used $48 \mathrm{~h}$ after changing media (midexponential growth phase). Cell viability was always $>95 \%$ as determined by trypan blue exclusion.

\$ Oleic acid was dissolved in absolute ethanol such that the final ethanol concentration was $0.5 \%$. The same ethanol concentration was present in the control experiments.

association rate is much faster than the dissociation rate. Essentially identical results are obtained when the experiments are performed under conditions where $H_{0}<R_{0}{ }^{3}$ (Fig. $7 \mathrm{~A}$ ), or where $\mathrm{H}_{0}=\mathrm{R}_{0}($ Fig. $7 \mathrm{~B})$. The rate constants calculated from the slopes of these lines are quite comparable for both groups of cells, although a slight increase in the $k_{a}$ during fasting cannot be ruled out. Such an effect, if present, must be quite small, since the near twofold increase in the halftime of dissociation

${ }^{3}$ In this context, $\mathrm{H}_{0}$ equals the media insulin concentration and $R_{0}$ equals the total receptor concentration. See legend to Fig. 7 for details.
TABLE III

Long-Term Effect (24 h) of Test Agents on IM-9 Cultured Lymphocytes*

\begin{tabular}{lc}
\hline \multicolumn{1}{c}{ Addition } & \% of control \\
\hline None & 100 \\
$\beta$-Hydroxybutyrate, $8 \mathrm{mM}$ & 99 \\
Acetoacetate, $5 \mathrm{mM}$ & 99 \\
Oleate, $1 \mathrm{mM}$ & 101 \\
Epinephrine, & \\
$1 \mu \mathrm{M}$ & 105 \\
$10 \mu \mathrm{M}$ & 96 \\
Glucagon, & \\
$1 \mathrm{nM}$ & 99 \\
$10 \mathrm{nM}$ & 96 \\
Growth hormone, & \\
$1 \mathrm{nM}$ & 105 \\
$10 \mathrm{nM}$ & 98 \\
\hline
\end{tabular}

* Data represent the mean of two experiments, and none of these differences approached statistical significance.

(Fig. 3) correlates quite well with the twofold increase in both the amount of insulin bound at low insulin concentrations (Fig. 1) and in the average affinity (Fig. 2).

Effects of substrate and hormone additions on insulin binding. Thus far, the data have demonstrated that fasting leads to an increase in the affinity of the insulin receptor by decreasing the insulin dissociation rate. It seemed possible that as a result of the fasting state, a change in the level of some metabolite or hormone could account for this effect. Consequently, we have tested the in vitro effects of several small molecules $(\beta$-hydroxybutyrate, acetoacetate, free fatty acids), hormones (epinephrine, glucagon, and growth hormone), and plasma from fasting rats on insulin binding to rat adipocytes, cultured IM-9 lymphocytes, and isolated human circulating mononuclear cells. Results are presented in Table II, which indicates that at all concentrations tested, these substances were without effect on insulin binding. Similar results were seen when incubations were performed at $37^{\circ} \mathrm{C}$ and when a variety of different buffers were employed. These studies represent relative short-term in vitro incubations, ${ }^{4}$ and to more closely reproduce the metabolic changes seen in fasting, IM-9 cultured lymphocytes were incubated for $24 \mathrm{~h}$ at $37^{\circ} \mathrm{C}$ with the test agents. As can be seen in Table III, no changes in insulin binding resulted from this maneuver.

${ }^{4}$ In the experiments described in Table II, the test agents were either added directly to the binding assay at the start of the experiment, or preincubated with the cells for up to $3 \mathrm{~h}$ before the binding assay. Since the results were uniformly negative, the data have been combined. 


\section{DISCUSSION}

We have previously shown that fasting leads to an increase in the binding affinity of the rat adipocyte insulin receptor (5). Wieringa et al. (27) have reported similar observations using rat adipocytes, and Bar et al. (6) and De Fronzo et al. (28) have found the same thing using human circulating mononuclear leukocytes. However, Lockwood et al. (29) and Kasuga et al. (30) have reported that fasting leads to an increase in receptor number with no change in receptor affinity, and we have no explanation for this apparent difference in experimental results. Nevertheless, it has become increasingly clear that insulin receptor affinity can be altered in a number of other situations, i.e., acute glucose ingestion (31), hypoglycemia (32), and acidosis (22). Thus, modulation of receptor affinity appears to be another way (in addition to changes in receptor number) to effect physiologic changes in insulin binding. The purpose of the present studies was to further elucidate the mechanisms of the fastinginduced increase in insulin receptor affinity which we have observed.

The results have clearly demonstrated that fasting does not primarily alter the rate at which insulin associates with its receptor, but does decrease the dissociation rate. Thus, since the affinity constant of the insulin binding reaction $\left(K_{A}\right)$ represents the ratio of the rate constants for association $\left(k_{a}\right)$ and dissociation $\left(K_{d}\right)$ (Eq. 2), the data indicate that the increase in binding affinity observed in fasting is due to a decrease in the rate at which insulin dissociates from its receptor. This conclusion is supported by the excellent correlation between the twofold increase in binding affinity (Figs. 1 and 2), and the near twofold increase in the half time of dissociation in fasting (Fig. 3).

It seems possible that some small molecule (substrate or hormone), affected by fasting, could mediate this change, and Merimee et al. (33) have recently reported that when cultured IM-9 lymphocytes are acutely exposed to $\beta$-hydroxybutyrate, insulin binding increases. As indicated in Tables II and III, we have been unable to confirm this observation despite a wide variety of experimental conditions, including the identical conditions used by Merimee et al. (33). No explanation for this difference is apparent. Furthermore, we cannot demonstrate any influence of a variety of substances (ketoacids, fatty acids, glucagon, epinephrine, or growth hormone) on three insulin receptor systems (adipocytes, IM-9 cultured lymphocytes, and circulating human mononuclear cells). Lastly, prolonged (24-h) exposure of IM-9 cells to these test agents did not alter this conclusion. Nevertheless, it is still possible that the fasting-induced change in receptor affinity is related to some intracellular or intramem- branous chemical change, the identification of which will require more direct approaches. On the other hand, adipocyte size decreases in fasting, and since the number of receptor sites per cell is unchanged, the density of receptors per unit of plasma membrane surface area must increase. Thus, an alternate possibility is that through some physical interaction, increased receptor density causes the observed increase in receptor affinity.

De Meyts et al. have presented evidence that insulin receptors exhibit negatively cooperative site-site interactions $(18,22,24,25)$. Such interactions also exist in rat adipocytes (17), and the current results indicate that cells from fasting animals also exhibit this phenomenon. Thus, the ability of unlabeled insulin to accelerate the dissociation of bound ${ }^{125}$ I-insulin can be easily demonstrated in cells from fasting animals, and the absolute magnitude of this effect is unchanged compared with control (Table I). On the other hand, the average affinity plot (Fig. 2) indicates that the $y_{f}$ and the percent receptor occupancy which elicits $50 \%$ of the cooperative effect, $\mathrm{C}_{\frac{1}{2}}$, are increased approximately twofold in fasting, and this should decrease the sensitivity of the cooperative effect to insulin. Nevertheless, the dose-response curves of the cooperative effect (Fig. 5) were quite similar for both groups of cells. However, since the binding affinity increases in fasting, this results in a higher fractional receptor occupancy for any given media insulin concentration, and this offsets the decreased sensitivity of the cooperative process. In this regard, it is interesting to note that the ability to bind insulin (Fig. 1), the average affinity, $y_{f}$, and $\mathrm{C}_{\frac{1}{2}}$ (Fig. 2) all increase approximately twofold, thus essentially completely counterbalancing each other.

The ability of hormones to activate their receptors has been attributed to either the degree of receptor occupancy (occupancy theory), or the frequency at which the hormone interacts with its receptor (rate theory) (34). The present data may bear on these alternate mechanisms. Thus, we have previously shown that in the early stages of fasting, the insulinglucose transport dose-response curve is shifted to the left, and the quantitative ability of occupied insulin receptors to activate the adipocyte glucose transport system is unchanged (5). Since insulin dissociation rates decrease in fasting, for any given level of receptor occupancy the number of association and dissociation events between insulin and receptors will be less. This suggests that it is occupancy rather than the rate of insulin-receptor interactions which "activates" the insulin receptor.

In summary, the results presented demonstrate that the fasting-induced increase in the affinity of the insulin receptor is due to a decrease in the insulin dissociation 
rate. The putative chemical mediator of this effect remains to be identified. If the adipocyte insulin receptor is considered as a structurally homogeneous set of binding sites, which all exhibit negatively cooperative interactions, then one could conclude that fasting inhibits the dissociation of insulin from all receptors. On the other hand, we have recently presented evidence that adipocyte insulin receptors do not behave as a kinetically homogeneous population (17). Thus, the interactions between insulin and adipocytes were best accounted for by receptors which exist in functionally distinct high- and low-affinity states, plus negative cooperative interactions. Therefore, in addition to increasing the affinity of all receptors, it is possible that fasting could also increase the proportion of receptors in the higher affinity state.

\section{ACKNOWLEDGMENTS}

This work was supported in part by funds from the Medical Research Service of the Veterans Administration, a grant from the American Diabetes Association, and by training grant AM 07217 from the National Institute of Arthritis, Metabolism, and Digestive Diseases of the National Institutes of Health.

\section{REFERENCES}

1. Gavin, J. R., III, J. Roth, D. M. Neville, Jr., P. De Meyts, and D. N. Buell. 1974. Insulin-dependent regulation of insulin receptor concentrations: a direct demonstration in cell culture. Proc. Natl. Acad. Sci. U.S.A. 71: 84-88.

2. Helderman, J. H., and T. B. Strom. 1977. Emergence of insulin receptors upon alloimmune $\mathrm{T}$ cells in the rat. $J$. Clin. Invest. 59: 338-344.

3. Roth, J., C. R. Kahn, M. A. Lesniak, P. Gorden, P. De Meyts, K. Megyesi, D. M. Neville, Jr., J. R. Gavin III, A. H. Soll, P. Freychet, I. D. Goldfine, R. S. Bar, and J. A. Archer. 1976. Receptors for insulin, NSILA-s, and growth hormone: applications to disease states in man. Recent Prog. Horm. Res. 31: 95-139.

4. Olefsky, J. M. 1976. The insulin receptor: its role in insulin resistance of obesity and diabetes. (Review). Diabetes. 25: 1154-1165.

5. Olefsky, J. M. 1976. Effects of fasting on insulin binding, glucose transport, and glucose oxidation in isolated rat adipocytes: relationships between insulin receptors and insulin action. J. Clin. Invest. 58: 1450-1460.

6. Bar, R. S., P. Gorden, J. Roth, C. R. Kahn, and P. De Meyts. 1976. Fluctuations in the affinity and concentration of insulin receptors on circulating monocytes of obese patients. Effects of starvation, refeeding, and dieting. $J$. Clin. Invest. 59: 1123-1135.

7. Rodbell, M. 1964. Metabolism of isolated fat cells. I. Effects of hormones on glucose metabolism and lipolysis. J. Biol. Chem. 239: 375-380.

8. Hirsch, J., and E. Gallian. 1968. Methods for the determination of adipose cell size in man and animals. $J$. Lipid Res. 9: 110-119.

9. Di Girolamo, M., S. Medlinger, and J. W. Fertig. 1971. A simple method to determine fat cell size and number in four mammalian species. Am. J. Physiol. 221: 850-858.

10. Freychet, P., J. Roth, and D. M. Neville, Jr. 1971.
Monoiodoinsulin:demonstration of its biological activity and binding to fat cells and liver membranes. Biochem. Biophys. Res. Commun. 43: 400-408.

11. Hunter, W. M., and F. C. Greenwood. 1962. Preparation of iodine-131 labeled human growth hormone of high specific activity. Nature (Lond.). 194: 495-496.

12. Olefsky, J., and G. M. Reaven. 1974. The human lymphocyte: a model for the study of insulin-receptor interaction. J. Clin. Endocrinol. Metab. 38: 554-560.

13. Gavin, J. R., III, P. Gorden, J. Roth, J. A. Archer, and D. N. Buell. 1973. Characteristics of the human lymphocyte insulin receptor. J. Biol. Chem. 248: 2202-2207.

14. Olefsky, J. M., P. Jen, and G. M. Reaven. 1974. Insulin binding to isolated human adipocytes. Diabetes. 23: $565-571$.

15. Olefsky, J. M., and G. M. Reaven. 1975. The effects of age and obesity on ${ }^{125} \mathrm{I}$-insulin binding to isolated rat adipocytes. Endocrinology. 96: 1486-1498.

16. Gammeltoft, S., and J. Gliemann. 1973. Binding and degradation of ${ }^{125}$ I-insulin by isolated rat fat cells. Biochim. Biophys. Acta. 320: 16-32.

17. Olefsky, J. M. 1977. Insulin binding to adipocyte receptors: evidence for interactions in addition to negative cooperativity. Diabetes. 26: (Suppl. 1): 353.

18. De Meyts, P., J. Roth, D. M. Neville, Jr., J. R. Gavin III, and M. A. Lesniak. 1973. Insulin interactions with its receptors: experimental evidence for negative cooperativity. Biochem. Biophys. Res. Commun. 55: 154-161.

19. Gliemann, J., K. Osterlind, J. Vinten, and S. Gammeltoft. 1972. A procedure for measurement of distribution spaces in isolated fat cells. Biochim. Biophys. Acta. 286: 1-9.

20. Olefsky, J. M. 1975. Effects of dexamethasone on insulin binding, glucose transport, and glucose oxidation of isolated rat adipocytes. J. Clin. Invest. 56: 1499-1508.

21. Olefsky, J. M., J. Johnson, F. Liu, P. Edwards, and S. Baur. 1975. A comparison of ${ }^{125} \mathrm{I}$-insulin binding to isolated rat hepatocytes and liver membranes. Diabetes. 24: 801-810.

22. De Meyts, P., A. R. Bianco, and J. Roth. 1976. Site-site interactions among insulin receptors. J. Biol. Chem. 251: $1877-1888$.

23. Boyum, A. 1968. A one-stage procedure for isolation of granulocytes and lymphocytes from human blood. General sedimentation properties of white blood cells in a $1 \mathrm{~g}$ gravity field. Scand. J. Clin. Lab. Invest. 21(Suppl. 97): $51-76$.

24. De Meyts, P. 1976. Cooperative properties of hormone receptors in cell membranes. J. Supramol. Struct. 4: $241-258$.

25. De Meyts, P., and J. Roth. 1975. Cooperativity in ligand binding: a new graphic analysis. Biochem. Biophys. Res. Commun. 66: 1118-1126.

26. Gliemann, J. 1976. Two groups of insulin "receptors" in rat adipocytes, one of them related to insulin degradation. Abstracts of the 12th Annual Meeting of the European Association for the Study of Diabetes, Helsinki, Finland. No. 98. 393.

27. Wieringa, T., J. Elzenga, and H. M. J. Krans. 1977. Increased insulin binding and decreased insulin response in adipocytes from diabetic and fasted rats. Program of the 13th Annual Meeting of the European Association for the Study of Diabetes, Geneva, Switzerland. Abstract No. 337.

28. De Fronzo, R., R. Sherwin, V. Soman, R. Hendler, and P. Felig. 1977. Dissociation of insulin binding to monocytes and insulin action in intact man during starvation and refeeding. Clin. Res. 25: 494A.

29. Lockwood, D. H., L. E. East, M. Kane, and J. N. Livingston. 1976. Effect of fasting on insulin binding and 
glucose transport by fat cells. Diabetes. 25(Suppl. I): 321 .

30. Kasuga, M., Y. Akanuma, Y. Iwamoto, and K. Kosaka. 1977. Effects of fasting and refeeding on insulin receptors and glucose metabolism in rat adipocytes. Endocrinology. 100: $1384-1390$.

31. Muggeo, M., R. S. Bar, and J. Roth. 1977. Change in affinity of insulin receptors following oral glucose in normal adults. J. Clin. Endocrinol. Metab. 44: 1206-1209.

32. Bar, R. S., P. Gorden, J. Roth, and C. W. Seibert. 1977.
Insulin receptors in patients with insulinomas: changes in receptor affinity and concentration.J. Clin. Endocrinol. Metab. 44: 1210-1213.

33. Merimee, T. J., A. J. Pulkkinen, and S. Lofton. 1976. Increased insulin binding by lymphocyte receptors induced by $\beta-\mathrm{OH}$ butyrate.J. Clin. Endocrinol. Metab. 43: $1190-1192$.

34. Birnbaumer, L. 1973. Hormone-sensitive adenyl cyclases: useful models for studying hormone receptor functions in cell-free systems. Biochim. Biophys. Acta. 300: 129-158. 